UDC $544.18+544.72$

A.G. Grebenyuk, V.N. Kaurkovskaya, V.V. Lobanov

\title{
THEORETICAL STUDY ON THE PRESSURE-INDUCED PHASE TRANSITION IN VANADIUM DIOXIDE
}

\author{
Chuiko Institute of Surface Chemistry of National Academy of Sciences of Ukraine \\ 17 General Naumov Str., Kyiv, 03164, Ukraine, E-mail: kavn@ukr.net
}

\begin{abstract}
The effect of external pressure on the parameters of phase transiton in vanadium dioxide has been studied theoretically by means of quantum chemistry with use of cyclic $\left(\mathrm{VO}_{2}\right)_{8}$ models with minimized strains in the closed chain. The external pressure was created by a regular ring of He atoms with decreasing $\mathrm{He}-\mathrm{He}$ interatomic distances confining vanadia species. The calculated values of external pressure related to phase transition in vanadium dioxide as well as those of transition energy have been found to argee well with literature data. When increasing the coordination number of vanadium atoms to that characteristic of the bulk structure, the necessary pressure has been found to decrease. Nevertheless, in general, this circumstance has no effect on the conclusion on aptitude of the cyclic model used.
\end{abstract}

Keywords: vanadium dioxide, phase transition parameters, quantum chemistry, cluster approach, confined space

\section{INTRODUCTION}

The attention paid recently to transition metal oxides with phase transitions (PT), in particular, to vanadium dioxide, is conditioned by a variety of probable applications of these materials in both optoelectronics and medicine as well as in chemical and light industry («electronic nose», «electronic tongue») [1-8]. Experimental and theoretical studies on the PT mechanisms in these materials are developed actively involving correlations between structural and electron transitions into consideration.

The phase transition of «insulator-metal» type (PTIM) in vanadium dioxide takes place at 338-340 K, accompanied by hopping changes in optical and electric properties of the substance. When the temperature amounts to that of phase transition (TPT), the resistance decreases for $2-5$ order of magnitude, a structural rearrangement occurs, the volume of the unit cell decreases (the cell is coarcted). Due to structural PTIM, a transition takes place from the monoclinic symmetry with altered vanadium-vanadium intrteratomic distances in the adjacent oxygen octahedra into the structure of tetragonal symmetry where those distances in the chains are identical. The problem of advantages of the Peierls and Mott model for PTIM is still discussed.
In the $\mathrm{VO}_{2}$ crystalline structure, vanadiumoxygen octahedra are grouped into layers, the $\mathrm{V}-\mathrm{O}$ interlayer bonds are less strong than those within the layers [5]. The change in the volume of unit cell under PTIM can have an effect on the stability of film coverings based on vanadium dioxide where the film integrity and stability have an essential importance. According to the literature data [6], the TPT in $\mathrm{VO}_{2}$ is dependent first of all on the size of particles inserted into the $\mathrm{SiO}_{2}$ support rather than on their stoichiometry or external pressure.

\section{METHODS}

Ribbon-ring vanadium dioxide models have been built of 8 formula units. The basic element of the structure is a chain of $\mathrm{O}-\mathrm{V}-\mathrm{O}$ fragments. The structures with minimized steric stresses in a closed ring were obtained due to optimization of the spatial structures of the models where coordination saturation (five-coordinated vanadium atoms as those at the surface) was reached by addition of water molecules. The optimization of the model clusters of semiconductor phase (SCP) and those of metallic phase (MP) was carried out with imposition of symmetry conditions within the point groups $D_{4 h}$ and $D_{8 \mathrm{~h}}$ respectively. The stuctures obtained were expanded due to external (instead of water molecules, model 1) and internal rings of $\mathrm{He}$ atoms (in order to obtain the maximum 
coordination saturation of vanadium atoms inherent to the bulk $\mathrm{VO}_{2}$ phase, i.e. coordination number $\mathrm{K}=6$, model 2). When decreasing the He$\mathrm{He}$ interatomic distance (and, respectively, the radius of external ring of helium atoms), the pressure increases. A set of optimized SCP and MP model clusters has been obtained where the radius of external ring of helium atoms is gradually decresed (with a pitch of $0.1-0.01 \AA$ ). In the model 2 with $K=6$, the radius of internal ring of helium atoms was assigned for the most «compressed» after PT model 1 at the distance of $\sim 2.2 \AA$ from the ring of the basic model for $\mathrm{VO}_{2}$.

The pressure was calculated as the first derivative of the total energy of the $\mathrm{VO}_{2}$ system with respect to its volume. The value of the volume of $\mathrm{VO}_{2}$ elementary cell for model clusters was believed to be $1 / 8$ of the toroid volume (as the models had the forms most close to a toroid), the Van der Waals radii for both vanadium and oxygen atoms being taken as $r_{\mathrm{s}} \sim 1.4 \AA$. The values of transition energy were evaluated from the plots of the total energy on the external pressure.

The calculations were carried out by HartreeFock-Roothaan method with basis set SBKJC by means of the program package PC GAMESS [9].

\section{RESULTS AND DISCUSSION}

The structures with minimized strains in the closed ring considered earlier are in Fig. $1 a$ as well as the models with external ring of $\mathrm{He}$ atoms (Fig. $1 b, c$ ) and internal one (Fig. $1 d, e$ ).

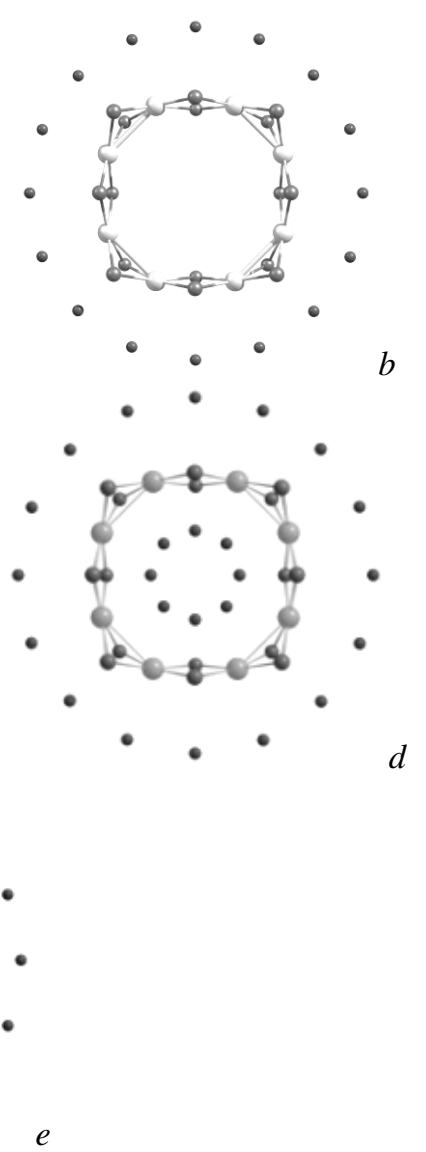

Fig. 1. Model clusters: $a-8 \mathrm{VO}_{2}\left(8 \mathrm{H}_{2} \mathrm{O}\right) ; b-8 \mathrm{VO}_{2}(16 \mathrm{He}) \mathrm{SCP} ; c-8 \mathrm{VO}_{2}(16 \mathrm{He}) \mathrm{MP} ; d-8 \mathrm{VO}_{2}(24 \mathrm{He}) \mathrm{SCP}$; $e-8 \mathrm{VO}_{2}(24 \mathrm{He}) \mathrm{MP}$

The models with altering vanadium-vanadium interatomic distances in the chain corresponded to the SCP (Fig. $1 b, d$ ) whereas those with equidistant $\mathrm{V}$ atoms simulated the MP (Fig. $1 c, e$ ).

The presence of additional energy levels within the forbidden zone [10] presumes the existance of stable high-spin states of $\mathrm{VO}_{2}$. Therefore the energy values were calculated for model structures with multiplicity $M=9$ (nonet) corresponding to metallic phase, i.e. to the presence of 8 unpaired electrons in the model. An analysis of the results calculated for the intermediate (triplet, quintet, and 
heptet) spin states of the models has shown these states to correspond to distorted structures. In the optimized structures of the hogh-spin states of the model systems of SCP, the interatomic V...V distances are equalized (become the same or slightly differ).

The plots of the total energy versus calculated pressure for the models with both one (external) and two (external and internal) rings of helium atoms are shown in Fig. 2.

When analyzing the results calculated for the model 1, definite structural changes in model clusters were found believed to be a phase transition. Similar structural changes were observed for the clusters with two rings of helium atoms (model 2, Fig. $1 d, e$ ). Practically it can be observed in a series of calculations with sequential 'compression' of model cluster (as it was noted above, the radius of external ring of helium atoms was decreased step-by-step for $0.1-0.01 \AA$ ), where under some pressure values the size of the elementary cell of the optimized model $8 \mathrm{VO}_{2}$ was not decreased but somewhat increased (a «counteraction» was observed to the external pressure). Therefore the first derivative of total energy with respect to the volume (pressure, absciss) had practically the same value for some values of the radius of external ring of helium atoms. Under further decrease in the radius of external ring (increase in pressure) the decrease in size of the elementary cell of the optimized models renewed.

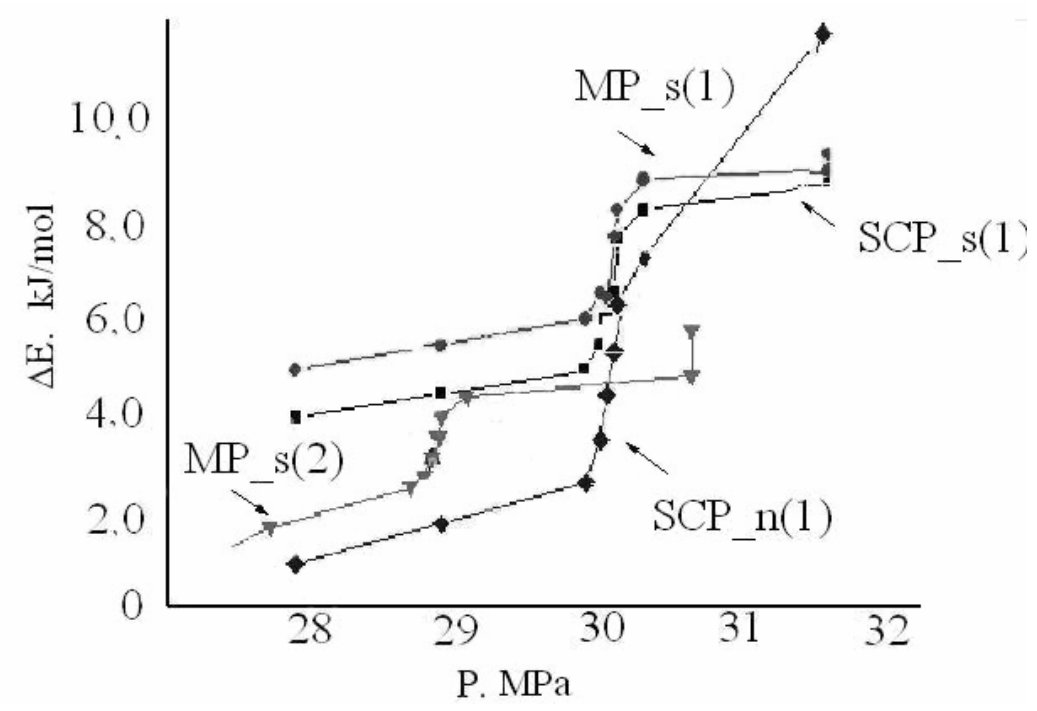

Fig. 2. Total energy dependences on the external pressure for: semiconductor model $(1)$ of singlet (SCP_s $(1))$ and nonet $\left(\mathrm{SCP} \_\mathrm{n}(1)\right)$ as well as for metal one (MP_s(1)) with one ring of helium atom (see visualization in Fig. $\left.1 b, c\right)$; for metal model (2) (MP_s(2)) with two rings of helium atoms (see visualization in Fig. $1 e$ )

It is seen from Fig. 2 that when increasing the coordination number of vanadium atoms to the interstructural level, the pressure value necessary for realization of the phase transition in the model 2 is less than that in the model 1 . Nevertheless this fact does not change general conclusions.

The values of transition energy $(\sim 3.1 \mathrm{~kJ} / \mathrm{mol}$ between SCP_s(1) and SCP_n(1), $\sim 1.5 \mathrm{~kJ} / \mathrm{mol}$ between SCP_s(1) Ta and MP_s(1)) and of external pressure necessary for the PTIM ( 30 MPa) agree with the known experimental data [2].

Some calculated PTIM parameters for vanadium dioxide models are summarized in the Table as compared with experimental data.
In the Table, the V...V distances in the models are given within the vicinity of structural changes fixed for PTIM. When analyzing those distances, the ratio of $\mathrm{V} \ldots \mathrm{V}$ distance difference for SCP to that for MP was taken as a structural factor. For the models, this ratio related to the ratio of $\mathrm{V} \ldots \mathrm{V}$ distance difference for $\mathrm{SCP}_{-}$s to the $\mathrm{V}$...V distance for SCP_n. It is seen from the Table that minimizing the model to a molecular cluster in comparison with vanadium dioxide real crystals slightly affects such parameters as the pressure necessary for PTIM realization whereas the value of transition enthalpy remains practically unchanged. 
Table. Calculated PTIM parameters for $\mathrm{VO}_{2}$ models $8 \mathrm{VO}_{2}(16 \mathrm{He}), 8 \mathrm{VO}_{2}(24 \mathrm{He})$ as compared with literature data

\begin{tabular}{|c|c|c|c|c|}
\hline $\begin{array}{c}\text { Object } \\
\text { Parameters }\end{array}$ & \multicolumn{2}{|c|}{$\begin{array}{c}\mathrm{VO}_{2}, \\
\text { Experiment }\end{array}$} & $\begin{array}{r}\text { Model 1 } \\
\text { 8VO }_{2}(16 \mathrm{He})\end{array}$ & $\begin{array}{r}\text { Model 2 } \\
\text { 8VO }_{2}(24 \mathrm{He})\end{array}$ \\
\hline $\begin{array}{l}\text { V...V distances at PTIM, } \AA \text { / } \\
\text { structural factor }\end{array}$ & $\begin{array}{c}\text { SCP } \\
\text { MP } \\
\text { SCP/MP }\end{array}$ & $\begin{array}{c}3.12 / 2.62 \AA \\
2.9 \AA \\
0.17\end{array}$ & $\begin{array}{c}2.37 \div 2.77 / 2.36 \div 2.76 \\
2.74 \div 2.73 \\
0.15\end{array}$ & $\begin{array}{c}2.5 \div 2.87 / 2.54 \div 2.86 \\
2.78 \div 2.77 \\
0.12\end{array}$ \\
\hline Pressure necessary for PTIM & \multicolumn{2}{|c|}{$320 \mathrm{MPa}$} & $\sim 30 \mathrm{MPa}$ & - \\
\hline Transition enthalpy, kJ/mol & \multicolumn{2}{|c|}{3.2} & $\sim 3.1$ & - \\
\hline
\end{tabular}

\section{CONCLUSIONS}

Vanadium dioxide molecular models have been designed with minimized steric stresses in the closed ring. The calculated values of external pressure necessary for realization of the phase transition in vanadium dioxide as well as the transition energies agree well with experimental data available in the literature. Thus, the parameters of phase transition in $\mathrm{VO}_{2}$ can be correctly estimated in a theoretical way by means of quantum chemical calculations of the properties of relatively simple cyclic models.

\title{
Теоретичне дослідження індукованого тиском фазового переходу у діоксиді ванадію
}

\author{
А.Г. Гребенюк, В.М. Каурковська, В.В. Лобанов \\ Інститут хімії поверхні ім. О.О. Чуйка Національної академії наук України \\ вул. Генерала Наумова, 17, Київ, 03164, Україна, kavn@ ukr.net
}

Вивчено вплив зовнішнього тиску на параметри фазового переходу у діоксиді ванадію з використанням ичиклічних моделей $8 \mathrm{VO}_{2}$ з мінімізованими напруженнями в замкнутому ланцюгу. Роль зовнішнього тиску виконувало зовнішне кільце з атомів Не, радіус якого зменшувався. Встановлено, що розраховані величини зовнішнього тиску, необхідного для здійснення фазового переходу в діоксиді ванадію, а також енергії переходу узгоджуються з відомими з літератури даними. Показано, що при збільшенні координаційного числа атомів ванадію до рівня внутрішньоструктурного тиск, який необхідний для здійснення фазового переходу, знижується, але загалом ие не впливає на загальні висновки про коректність використання циклічної моделі.

Ключові слова: діоксид ванадію, параметри фазового переходу, кластерне наближення, обмежений простір

\section{Теоретическое исследование индуцированного давлением фазового перехода в диоксиде ванадия}

\author{
А.Г. Гребенюк, В.Н. Каурковская, В.В. Лобанов
}

Институт химии поверхности им. А.А. Чуйко Национальной академии наук Украины ул. Генерала Наумова, 17, Киев, 03164, Украина, kavn@ukr.net

Изучено влияние внешнего давления на параметры фазового перехода в диоксиде ванадия с использованием ииклических моделей $8 \mathrm{VO}_{2}$ с минимизированными напряжениями в замкнутой цепи. Роль внешнего давления исполняло внешнее кольцо из атомов Не, радиус которого уменьшался. Установлено, что рассчитанные величины внешнего давления, необходимого для осуществления 
фазового перехода в диоксиде ванадия, а такюе энергии перехода согласуются с известными из литературы данными. Показано, что при увеличении координационного числа атомов ванадия до уровня внутриструктурного давление, необходимое для осуществления фазового перехода, снижается, однако в целом это не влияет на общие выводы о корректности использования цииклической модели.

Ключевые слова: диоксид ванадия, параметры фазового перехода, кластерное приближение, ограниченное пространство

\section{REFERENCES}

1. Strelcov E., Lilach Y., Kolmakov A. Gas Sensor based on metal-insulator transition in $\mathrm{VO}_{2}$ nanowire thermistor, Nano Lett., 9 (2009) 2322.

2. Balakrishnan V., Ko Ch., Ramanathana Sh. Insitu studies on twinning and cracking proximal to insulator-metal transition in self-supported $\mathrm{VO}_{2} / \mathrm{Si}_{3} \mathrm{~N}_{4}$ membrane, J. Mater. Res., 27 (2012) 1476.

3. Andreev V.N., Klimov V.A. Effect of deformation on the metal-semiconductor phase transition in vanadium dioxide thin films, Physics of the Solid State, 53 (2011) 577.

4. Kim H., Chae B., Youn D. et al. Mechanism and observation of Mott transition in $\mathrm{VO}_{2}-$ based two- and three-terminal devices, New J. Phys., 6 (2004) 52.

5. Ibisate M., Golmayo D., López C. Vanadium dioxide thermochromic opals grown by chemical vapour deposition, J. Opt. A: Pure Appl. Opt., 10 (2008) 125202.

6. Nag J., Haglund R.F., Jr. Synthesis of vanadium dioxide thin films and nanoparticles, J. Phys.: Condens. Matter, 20 (2008) 264016.

7. Cavalleri A., Tóth Cs., Siders C.W. et al. Femtosecond structural dynamics in $\mathrm{VO}_{2}$ during an ultrafast solid-solid phase transition, Phys. Rev. Lett., 87 (2001) 237401.

8. Boriskov P.P., Velichko A.A., Pergament A.L. et al. The effect of electric field on metalinsulator phase transition in vanadium dioxide, Technical Physics Letters, 28 (2002) 406.

9. Schmidt M.W., Baldridge K.K., Boatz J.A. et al. General atomic and molecular electronic structure system, J. Comput. Chem., 14 (1993) 1347.

10. Kim H.-T., Chae B.-G., Youn D.-H. et al. Mechanism and observation of Mott transition in $\mathrm{VO}_{2}$-based two- and three-terminal devices, New J. Phys., 6 (2004) 52.

Received 31.07.2014, accepted 23.04.2015 